\title{
GENETIC AND PHENOTYPIC ASPECTS OF THE BODY MEASURED TRAITS IN MERINOLANDSCHAF BREED OF SHEEP
}

\author{
M.P.Petrović ${ }^{1}$, V. Caro Petrović ${ }^{1}$, D. Ružić Muslić ${ }^{1}$, Z. Ilić ${ }^{2}$, Z. Spasić \\ J.Stojković ${ }^{2}$ M. Milenković \\ ${ }^{1}$ Institute for Animal Husbandry, Po.Box.23, Belgrade, 11080 Zemun, Serbia. \\ ${ }^{2}$ Faculty of Agriculture, Kopaonicka bb, 38219 Lesak, Serbia \\ Corresponding author: milanppet@yahoo.com \\ Original scientific paper
}

Abstract: Merinolandschaf sheep breed was used to estimate relationship between the next traits: Body weight of adult ewes (BW), Height to withers (HW), Body length (BL), Girth of Chest (GC), Rump Width (RW), Body weight of lambs at birth (BWB), Body weight of lambs at weaning (BWW). The collected data were from 750 sheep and their lambs during the period of three year. Estimates of means and standard errors for linear body measures and body weight of adult ewes and lambs, were obtained using the software program SPSS (2006). To estimate genetic and phenotypic correlations of observed traits, the ASREML program was used. Research has shown that genetic correlations between BW and all body measures of dams, ranging from 0.728 (BW-GC) to 0.976 (BW-HW). Genetic correlation between body measures of dams have also been positive and ranged in the interval from 0.873 (HW-GC) to 0.999 (BL-GC). Values for phenotypic correlations were lower compared with the genetic and the range varied from 0.183 (RW-BWB) to 0.421 (GC-BWW). The weaker phenotype correlations can be interpreted as play of more complex genetic and residual factors.

Key words: Genetic correlations, phenotypic correlations, body measures,sheep

\section{Introduction}

Testing and characterization of different breeds in the world is of particular interest for the future of sheep production (Ugarte, 2007; Kurt And Horst, 2008). The production traits of sheep depend on a number of genetic and non-genetic factors (Petrović et al., 2009). Farmers use different selection methods for 
improving the quality of their herds and select the best animals for further reproduction (Safari et al., 2005). Growth usually defined as the increase in size or body weight at a given age, is one of the important selection criteria for improvement of lamb production (Afolayan et al., 2006). Conventional methods of selection of sheep mainly take into account the fertility and quality of offspring given by a sheep or their ancestors. In other words, animals are usually estimated by what benefits they can give to farmers. At first glance this is quite normal, but not completely. Linear body measurements taken on live animals have been widely used in research work as a simple means of recording certain aspect of animal growth and shape (Salako, 2006; Alphonsus et al., 2010). Linear measurement can be used in assessing growth rate, weight, feed utilization and carcass characteristic, for tracing relationship between production performance, visual appraisal and body measurements (Lawrence and Fowler, 1998; Fourie et al., 2002). To determine optimal breeding strategies to increase the efficiency of sheep production, knowledge of genetic parameters for weight traits and also the genetic relationships between the traits in different breed of sheep is needed (Neser et al., 2001; Jamssems and Vandepitte, 2004; Babar et al., 2008, Bahreini Behzadi et al., 2007; Komlosi, 2008; Gamasaee et al., 2010).

Merinolandschaf breed of sheep began to be increasingly imported from germany to serbia during the nineties. In addition to growing pure breed, it is also used for crossbreeding with local populations (Petrović, 2000). Among all the foreign breeds, it is the most represented breed of sheep in the country. It is used for the production of lamb meat, so that the body characteristics of sheep and lambs have special interest. There are no reports on genetic parameters for growth traits of Merinolandschaf breed of sheep.

The objective of this study was to estimate relationships between body development traits of Merinolandschaf sheep breed, or more precisely genetic and phenotypic correlation of linear body measurements of dams with their body weight and the body weight of their lambs.

\section{Material and methods}

The data used in the present study were collected during period of three years. A total of 750 controlled sheep after first, second and third lambing were included in the analysis. The animal observed were all Merinolandschaf sheep breed and was imported from Germany. The experiment included 200 lambs, after each lambing. The next traits of dams were considered: Body weight (BW), Height to withers (HW), Body length (BL), Girth of Chest (GC), Rump Width (RW). The following traits of lambs (from the observed dams) were considered: body weight at birth (BWB), body weight at weaning-3 months (BWW). 
Body weight and linear measures of sheep were controlled after shearing each year in June. Lambs were weighed at birth and once a month until weaning at 3 months of age.

Height to withers (HW) was measured as the distance from the surface of a platform to the withers. Body length (BL) was measured at the distance from the external occipital protuberance to the base of the tail. Rump Width (RW) was measured as the distance between pinbones. Girth of Chest (GC) represented the circumference of the chest. The animals were weighed by sheep weighing balance ( \pm 100 gms). The body measurements were taken through the sheep measuring tools $( \pm 1 \mathrm{~cm})$.

Main source of feed during the spring-summer season was the natural pasture, without any additives. During the autumn-winter season, the sheep were fed hay, silage and concentrate. The quality of feeds varied every year of observation, but not significantly. Lambing season was from January to March, and lambs were kept with their mothers while in the special box received high-quality hay and a concentrate with $18 \%$ of protein.

Statistical analysis was performed using a fixed effect model (Yijk $=\mu+$ $\mathrm{Gi}+\mathrm{Sj}+$ eijk) where year and sex, was fitted using the GLM procedure of SPSS (2006). To estimate genetic and phenotypic correlations of observed traits, the ASREML program (Gilmour et al. (1999) was used.

\section{Results and discussion}

Estimates of means and standard errors for dams body measures and body weight of lambs given in Table 1 . We can see in this table that the sheep has well expressed height, length and width, that is well built body frame. However the body weight of $54.64 \pm 0.22 \mathrm{~kg}$ is under the results in Germany (Seibert et al., 2004) where they were imported. This is due to extensive breeding conditions during spring-summer season. On the other side, body weight of lambs and gain is similar as in Germany. Also shown in same table, the effect of the year on all traits of body measures and body weight was very significant $(\mathrm{P}<0.01)$. We can also see that the effect of lamb sex was significant at a lower level $(\mathrm{P}<0.05)$. 
Table 1. Means and standard errors for linear body measures and body weight of dams and lambs

\begin{tabular}{|l|c|c|c|c|c|}
\hline \multirow{2}{*}{ Traits } & \multirow{2}{*}{$\mathrm{N}$} & Mean & $\mathrm{SE}$ & \multicolumn{2}{|c|}{ Effects } \\
\cline { 5 - 6 } & & & Year & Sex \\
BW & 750 & 54.64 & \pm 0.22 & $* *$ & \\
HW & 750 & 73.22 & \pm 0.13 & $* *$ & \\
BL & 750 & 72.11 & \pm 0.17 & $* *$ & \\
GC & 750 & 97.66 & \pm 0.19 & $* *$ & $*$ \\
RW & 750 & 25.82 & \pm 0.07 & $* *$ & $*$ \\
BWB & 600 & 4.98 & \pm 0.03 & $* *$ & $*$ \\
BWW & 580 & 27.16 & \pm 0.08 & $* *$ & \\
\hline
\end{tabular}

$*_{-} \mathrm{P}<0.05 ; * *-\mathrm{P}<0.01$

Table 2 (above diagonal) indicates strong positive genetic correlations between BW and all body measures of dams, ranging from 0.728 (BW-GC) to 0.976 (BW-HW). The correlation between body measures of dams have also been very positive and ranged in the interval from 0.873 (HW-GC) to 0.999 (BL-GC). Similar to our research, Moktar and Farhad et al. (2011) stated that genetic correlations between traits of body weight and body measurements in Makooei sheep were positive and ranged from low to high (0.15-0.99), which indicated that traits were genetically linked.

Borg et al. (2009) in a herd of Targhee breed of sheep found strong genetic correlations between BW and BCS (body condition score), respectively, reflecting high repeatabilities of these traits. In the other literature can too find that genetic correlations of the body measures in sheep are positive (Duguma et al., 2002 and Salako, 2006b). From Table 2 (below diagonal), we can see results for phenotypic correlation between observed traits of sheep. Results of phenotypic correlations varied from weak to medium. The values of correlations between BW and all linear body measures ranging from 0.235 to 0.591 . Phenotypic correlation between linear body measures of dams varied in the range from 0.302 (RW-BL) to 0.613 (GC$\mathrm{BL}$ ). It is evident that the values of phenotypic correlations are less than genetic. Similar results found out by Bahreini Behzadi et al. (2007), stated that phenotypic correlations between various stages of body development in Kermani sheep were positive and generally less than corresponding genetic correlations. 
Table 2. Estimates of genetic correlations (above diagonal) and phenotypic correlations (below diagonal) between linear body measures of dams

\begin{tabular}{|l|c|c|c|c|c|}
\hline Traits & BW & HW & BL & GC & RW \\
\hline BW & - & $0.976^{* *}$ & $0.785^{* *}$ & $0.728^{* *}$ & $0.730^{* *}$ \\
HW & $0.591^{* *}$ & - & $0.914^{* *}$ & $0.873^{* *}$ & $0.875^{* *}$ \\
BL & $0.422^{*}$ & $0.432^{*}$ & - & $0.999^{* *}$ & $0.989^{* *}$ \\
GC & $0.484^{*}$ & $0.467^{*}$ & $0.613^{* *}$ & - & $0.998^{* *}$ \\
RW & 0.235 n.s. & 0.307 n.s. & 0.302 n.s. & $0.392^{*}$ & - \\
\hline
\end{tabular}

n.s. Correlation was not significant, ${ }^{* *}$ Correlation is significant at the 0.01 level, ${ }^{*}$ Correlation is significant at the 0.05 level

Gamasaee et al. (2010) found that phenotypic correlation estimates in Mehraban sheep were generally lower than those of genetic correlation. Afolayan et al. (2006) stated that variables such as height, length, girth, which are directly related to the size and weight of Yankasa sheep, displayed moderate to very high positive correlations with one another (0.79-0.87). In our study, we paid special attention to the connection between body measures of dams and body weight of lambs, because it is a very interesting parameter for the practical breeding of sheep (Table 3).

Table 3. Estimates of genetic correlations between linear body measures of dams and body weight of lambs

\begin{tabular}{|l|c|c|}
\hline \multirow{2}{*}{ Traits of dam } & \multicolumn{2}{|c|}{ Traits of lambs } \\
\cline { 2 - 3 } & BWB & BWW \\
\hline BW & $0.986^{* *}$ & $0.899^{* *}$ \\
HW & $0.992^{* *}$ & $0.987^{* *}$ \\
HL & $0.945^{* *}$ & $0.993^{* *}$ \\
GC & $0.906^{* *}$ & $0.969^{* *}$ \\
RW & $0.907^{* *}$ & $0.974^{* *}$ \\
\hline
\end{tabular}

**Correlation is significant at the 0.01 level 
There is an evident of strong genetic correlation between the body weight of sheep and lambs body weight at birth (0.986-BWB) and at weaning (0.899BWW). It also shows that there is a strong positive genetic correlation (over the value of 0.900 ) between all linear measures of sheep and lambs body weight on investigated age. Our findings agree or slightly higher in comparison with other authors. Hussain et al. (2000) found that the weight of dams had a positive correlation with body weight of lambs at birth. Matika et al.(2001), in a flock of Sabi Sheep discovered that the genetic correlation between birth weight and ewe weights (mating, post-partum and dam weight at weaning of lamb) were moderate viz. $0.51,0.400 .49$ respectively and were close to unity at 18 months of age viz. $0.96,0.92,0.84$ respectively. There is a positive genetic correlation between body weight of sheep and lambs and are confirmed with the studies of Mousa et al. (1999). There were high additive genetic correlations between muscle mass and type of land sheep breeds in Germany (De Vries et al., 2003).

The values of phenotypic correlation (table 4) between measures of dams and body weight of lambs are less in comparison with genetic correlations. Variations areal of phenotypic correlation were from 0.183 (RW-BWB) to 0.421 (GC-BWW). The weaker phenotype correlations can be interpreted as play of more complex genetic and residual factors. Everett-Hincks and Dodds (2008) reported the importance of environmental effects of mother body condition score on weaning lamb weight traits and showed a weak positive phenotypic correlation (rp=0.09). Bahreini Behzadi (2007) stated that phenotypic correlations between various stages of body development in Kermani sheep were generally less than corresponding genetic correlations.

Table 4. Estimates of phenotypic correlations between body measures of dams and body weight of lambs

\begin{tabular}{|l|c|c|}
\hline \multirow{2}{*}{ Traits of dam } & \multicolumn{2}{|c|}{ Traits of lambs } \\
\cline { 2 - 3 } & BWB & BWW \\
\hline BW & 0.258 n.s. & $0.368^{*}$ \\
HW & 0.187 n.s. & 0.254 n.s. \\
HL & 0.207 n.s. & 0.287 n.s. \\
GC & 0.250 n.s. & $0.421^{*}$ \\
RW & 0.183 n.s. & 0.205 n.s. \\
\hline
\end{tabular}

n.s. Correlation was not significant, ${ }^{*}$ Correlation is significant at the 0.05 level 


\title{
Conclusions
}

Our research has shown that there is a positive relationship between all investigated body measures of sheep. There is a high genetic correlation between linear body measures of dams and body weight of lambs at birth and weaning. The genetic correlation is strongly expressed between measures of body weight of mothers and their lambs at birth, while the body weight of lambs at weaning had a greater impact of environmental factors and other non-genetic parameters. Relationships between observed traits in this study indicate that selection for greater body measures can increase body weight of sheep and lambs. Phenotypic correlations were less than genetic, which is consistent with cited authors.

\section{Acknowledgement}

This study is part of the projects TR 31053 "Modern biotechnology solutions in the breeding and feeding of cattle sheep and goats for the production of valuable and safety food" and TR 31001 "An environmental approach and implementation of modern biotechnologies as a basis for the improvement of ruminant breeding technology", and financially supported by the Ministry of Education, Science and Technological Development of the Republic of Serbia.

\section{Genetički i fenotipski aspekti osobina telesnih mera Merinolandschaf rase ovaca}

\author{
M.P.Petrović, V. Caro Petrović, N. Maksimović, D. Ružić Muslić, Z. Ilić, Z. \\ Spasić, J.Stojković
}

\section{Rezime}

Merinolandschaf ovce su korišćene za procenu odnosa između sledećih osobina: Telesna masa odraslih ovaca (BW), visina grebena (HW), dužina tela (BL), obim grudi (GC), širina karlice (RW), telesna masa jagnjadi na rođenju (BWB) Telesna masa jagnjadi pri odlucivanju (BWW). Prikupljeni podaci potiču od 750 ovaca i njihove jagnjadi tokom perioda od tri godine. Procene sredina $i$ standardnih grešaka za linearne telesne mere i telesne mase odraslih ovaca i jagnjadi, genetske i fenotipske korelacije, dobijeni su korišćenjem softvera SPSS (2006). Istraživanja su pokazala da genetske korelacije između BW i svim ostalim telesnim merama variraju, u rasponu od 0.728 (BW-GC) do 0.976 (BW-HW). Genetski korelacija između telesnih mera varirale su u pozitivnom opsegu od 0.873 
(HW-GC) do 0.999 (BL-GC). Vrednosti fenotipskih korelacija bile su niže u poređenju sa genetskim u intervalu variranja od 0.183 (RW-BWB) do 0.421 (GCBWW). Slabije fenotipske korelacije možemo tumačiti kao igru složenijih genetskih faktora i nedeterminisanih efekata.

\section{References}

AFOLAYAN R. A., ADEYINKA I. A., LAKPINI C. A. M.(2006): The estimation of live weight from body measurements in Yankasa sheep. Czech J. Anim. Sci. 51, 343-348.

ALPHONSUS C., FINANGWAI H. I., YASHIM S. M., AGUBOSI O. C. P., SAM I.M.(2010): Effect of dam parity on measures of growth in Red sokoto goats 1,3,6, and month of age. Continental J. Animal and Veterinary Research. 2, $9-13$.

BABAR M. E., ABDULlAH M., JAVED K., ALI A., AHMAD N.(2008): Phenotipic and genetic correlations between age and weight at first service in Lohi sheep. J. Anim. P1. Sci. 18,11-13.

BAHREINI BEHZADI M. R., SHAHROUDI F. E., VAN VLECK L. D.(2007): Estimates of genetic parameters for growth traits in Kermani sheep Journal of Animal Breeding and Genetics, 124, 296-301.

BORG R C., NOTTER D. R., KOTT R. W. (2009): Phenotypic and genetic associations between lamb growth traits and adult ewe body weights in western range sheep J. Anim. Sci. 87, 3506-3514.

DE VRIES F., HAMANN H., DISTL O.(2003): Schätzung genetischer Parameter für Landschafrassen. Arch. Tierz. 47, 351-358.

DUGUMA G., CLOETE W.P, SCHOEMAN S. J., JORDAAN G. F.(2002): Genetic parameters of testicular measurements in Merino rams and the influence of scrotal circumference on total flock fertility. S. Afr. J. Anim. Sci. 32, 76-80.

EVERETT-HINCKS J.M., DODDS K.G.(2008): Management of maternaloffspring behavior to improve lamb survival in easy care sheep systems. J. Anim. Sci. 86,259-270.

FOURIE P. J, NESER F. W. C., OLIVIER J. J., DER WESTHUIZEN C. V. (2002): Relationship between production performance, visual appraisal and body measurements of young Dorper rams. S. Afr. J. Anim. Sci. 32,256-262.

GAMASAEE V. A., HAFEZIAN S. H., AHMADI A., BANEH H., FARHADI A., MOHAMADI A. (2010): Estimation of genetic parameters for body weight at different ages in Mehraban sheep. African Journal of Biotechnology. 9, 5218-5223. GILMOUR A.R., CULLIS B. R., WELHAM S.J., THOMPSON R. (1999): ASREML reference manual. NSW Agriculture Biometric Bulletin No 3. NSW Agriculture, Orange, NSW, Australia.

HUSSAIN A., BABAR M. E., ALI S., UL-HASAN Z.(2000): Effect of body weight of ewes on birth weight of lambs in Rambouillet breed of sheep. Pak.Journal of Biological Science. 3, 179-180. 
JAMSSEMS S., VANDEPITTE W.(2004): Genetic Parameters for body measurements and linear type traits in Bleu du maine, Suffolk and Texel sheep. Small ruminant Research. 54,13-24.

KOMLOSI I. (2008): Genetic Parameters for growth traits of the Hungarian merino and meat sheep breeds in Hungary. Applied Ecology and Environmental Research. 6, 77-84.

KURT G., HORST R. B.(2008): Development and characterization of lambs' coats of East Prussian Skudden and Rough-coated Pomeranian Landrace sheep. Arch. Tierz., Dummerstorf. 51, 467- 478.

LAWRENCE T. I. J., FOWLER V. R . (1998): Growth on farm animals. CAB international pp. 271-283.

MATIKA O. J., VAN WYK B., ERASMUS G. J., BAKER R. L. (2001): Phenotypic and genetic relationships between lamb and ewe traits for the Sabi sheep of Zimbabwe. South African Journal of Animal Science. 31, 215-222.

MOKHTAR A .A., FARHAD G. K. (2011): Genetic (Co)variance Components for Body Weight and Body Measurements in Makooei Sheep. Asian-Aust. J. Anim. Sci. 24, $739-743$.

MOUSA E., VAN VLECK L. D., LEYMASTER K. A.(1999): Genetic parameters for growth traits for a composite terminal sire breed of sheep. J. Anim. Sci.77:1659-1665.

NESER F. W. C., ERASMUS G. J., VAN WYK J. B. (2001): Genetic parameter estimates for pre-weaning weight traits in Dorper sheep. Small Rumin. Res. 40, 197-202.

PETROVIĆ P. M (2000): Genetic and improvement of sheep. Sci. Book, Belgrade. pp. 365.

PETROVIĆ P. M., RUŽIĆ-MUSLIĆ, D., MAKSIMOVIĆ, N., MEMIŠI, N.(2009): Effect of environmental and paragenetic factors on birth mass variability of Mis sheep populations. Biotechnology in Animal Husbandry. 25,213-219.

SAFARI E., FOGARTY N. M.,GILMOUR A. R.(2005): A review of genetic parameter estimates for

wool, growth, meat and reproduction traits in sheep. Livest. Prod. Sci. 92, 271-289. SALAKO A. E.(2006): Application of morphological indices in the assessment of type and Function in sheep. International Journal of Morphology. 24, $13-8$.

SALAKO, A. E.(2006B): Principal component factor analysis of the morphostructure of immature Uda sheep. Int. J. Morph. 24,571-574.

SEIBERT B., MATTHIAS G., GEORG E.(2004): Productivity of different sheep breeds in extensive pasture management. Arch. Tierz. Dummerstorf. 47,142152.

UGARTE E. (2007): The Breeding program of Latxa Breed. Biotechnology in Animal Husbandry, 5-6, 97-111. 